\title{
Comparison of In Vitro Testing Antifungal Activity between Rosemary Essentials Oil and Fluconazol on Candida species Isolate from HIV/AIDS Patients with Candidiasis Oral
}

\author{
Putri Intan Primasari, Dwi Murtiastutik ${ }^{1}$, Pepy Dwi Endraswari ${ }^{2}$, Cita Rosita Sigit \\ Prakoeswa $^{1}$, Evy Ervianti ${ }^{1}$ \\ ${ }^{I}$ Department of Dermatology and Venereology, Faculty of Medicine, Universitas Airlangga/Dr. \\ Soetomo General Academic Teaching Hospital, Surabaya, Indonesia \\ ${ }^{2}$ Department of Microbiology, Faculty of Medicine, Universitas Airlangga/Dr. Soetomo General \\ Academic Teaching Hospital, Surabaya, Indonesia
}

\begin{abstract}
Background: The most common opportunistic infection obtained in patients with Human Immunodeficiency Virus (HIV)/Acquired Immune Deficiency Syndrome (AIDS) is Oral Candidiasis (OC). Currently widely reported about increased fluconazole resistance, as a therapy that is often used in patients with HIV/AIDS with OC. For this reason, effective antifungal agents are needed as alternative therapies. Several studies have reported some antifungal activity from rosemary essential oils. Purpose: The aim of this study is to evaluate the antifungal activity between rosemary essential oils and fluconazole against the isolates used by Candida sp. taken from HIV / AIDS patients with OC. Methods: This research was an experimental laboratory study with a post-test only design of 40 Candida $s p$. isolates from HIV / AIDS patients with OC in the Outpatient Unit and Inpatient Installation of the Infectious Disease Intermediate Care Unit (UPIPI) Dr. Soetomo General Academic Teaching Hospital, Surabaya. Examination of antifungal activity using conventional test methods with disk diffusion. Result: Disk diffusion test result revealed average inhibition zone of rosemary essential oil in Candida albicans 1,75 $\pm 3,64 \mathrm{~mm}$ and Candida non-albicans 1,5 $\pm 3,08 \mathrm{~mm}$, while the average inhibition zone of fluconazole in Candida albicans 17,9 $\pm 8,62 \mathrm{~mm}$ and Candida non-albicans $4,85 \pm 7,9 \mathrm{~mm}$. There was significant difference $(\mathrm{p}<0.001)$ between the inhibition zone formed in Candida albicans by fluconazole and rosemary essential oil, but no significant difference of inhibition zone formed in Candida non-albicans. Conclusion: Antifungal activity fluconazole has greater than Rosemary essential oils in Candida albicans.
\end{abstract}

Keywords: Antifungal activity, Candida albicans, Candida non-albicans, essential oils, flukonazole, Rosmarinus officinalis.

Correspondence: Evy Ervianti, Department of Dermatology and Venereology Faculty of Medicine, Universitas Airlangga/Dr. Soetomo General Academic Hospital, Jl. Mayjen Prof. Dr. Moestopo No. 6-8 Surabaya 60131, Indonesia. Phone: (031) 5501609, e-mail: evy_if@yahoo.co.id.

\section{BACKGROUND}

Oral candidiasis (OC) is an opportunistic infection by the fungus Candida sp. which attacks the oral cavity. Candida sp. is a normal flora in the body and is most abundant in the oral cavity. ${ }^{1} \mathrm{OC}$ is the most common opportunistic infection found in patients infected with Human Immunodeficiency Virus (HIV). ${ }^{2}$ Acquired Immunodeficiency Syndrome (AIDS) is a disease with high mortality and mordibity rates. In some countries it is known as a leading cause of death. The development of HIV / AIDS cases in Indonesia based on data from the Directorate General of Disease Control and Environmental Health Ministry of Health (Ditjen PP \& PL Ministry of Health) in 2017 shows the number of new cases of patients with HIV / AIDS as many as 14,640 people and the number of cumulative cases from 1987 to 2017 as many as 280,623 people. East Java Province ranks second highest after DKI Jakarta for the number of HIV infections, amounting to

\section{$39,633 .^{3}$}

Candida albicans is the most reported etiology of fungal-causing fungi, but at this time an etiological change has begun to change to Candida non-albicans. Other studies report a significant correlation between the number of low cluster of differentiation-4 (CD4) 200 cells $/ \mu \mathrm{L}$ on the incidence of OC. ${ }^{4}$ Retrospective research in 2013 at RSUD Dr. Soetomo Surabaya showed $81.1 \%$ of patients suffering from HIV / AIDS with $\mathrm{OC}$ in the Infectious Disease Intermediate Care Unit of the total patients with skin manifestations. ${ }^{5}$

The World Health Organization (WHO) recommends fluconazole and miconazole as first-line therapy in cases of HIV \& AIDS with OC. ${ }^{6}$ Fluconazole is a safe, inexpensive, effective, and available antifungal option in Indonesia. In the clinical practice guide for Indonesian dermatologists in 2017 and practice guide for Dermatology Functional Medical Unit Dr. Soetomo Surabaya in 2014 from the 
two guidelines, fluconazole was a drug that was used quite often. ${ }^{7,8}$

The widespread use of fluconazole in cases of OC was reported to be associated with a decrease in sensitivity of in vitro fluconazole to Candida sp. Several other factors that influence the decrease in sensitivity to OC therapy with azole groups against Candida sp. among others, changes in causative species from albicans to non-albicans that have intrinsic resistance such as C. glabrata and C. krusei. Since it was first discovered in 1990, the incidence of antifungal agent resistance to Candida species from HIV / AIDS patients with OC has been reported to increase. ${ }^{9}$ Fluconazole resistance data at RSUD Dr. Soetomo by using the disk diffusion method as a resistance test method, found fluconazole resistant to 18 of 37 (48.6\%) Candida resistance isolates and most species were Candida non-albicans. ${ }^{10}$

Lately, research on herbal essential oils has turned out to have antifungal effects. The results are expected to be obtained as an alternative therapy to replace antifungal drugs that have been resistant. The pharmacological properties of these medicinal plants have been extensively studied in phytotherapy. In several studies reported the presence of antifungal effects of rosemary essential oils. ${ }^{11,12}$ Antifungal activity has been reported in research by Delich et al investigated rosemary essential oil compared with fluconazol against Candida species isolates, showing means of diameter zone inhibition of 5\% rosemary essential oil was $11.17 \pm 0,19$ and better when compared to $2 \mathrm{mg} / \mathrm{ml}$ fluconazole. ${ }^{12}$

\section{METHODS}

This research was an experimental laboratory study with a posttest only design conducted in Dr. Soetomo General Hospital, Surabaya. Fourty isolates divided in two groups 20 isolates of $C$. albicans and 20 isolates Candida non-albicans used in this study, were obtained from fourty patients Candidiasis oral with HIV/AIDS infection. Candida non-albicans species included in this study consisted of 9 species of Candida krusei, 4 species of $C$. glabrata, 2 species of $C$. dubliniensis, 2 species of $C$. parapsilosis, 2 species of C. tropicalis and 1 species of C. lypoitica. Analyzed essensial of Rosemary (Rosmarinus officinalis L.), were commercial product produced by Youngliving, Ltd. (Canada, United State), compare of flukonazol $2 \mathrm{mg} / \mathrm{dl}$. This essensial oil were analyzed by gas chromatograph (GC) containing 45.12\% 1.8-cineol, $12,78 \%$ alpha-pinene, $10.79 \%$ camphor, $3,50 \%$ borneol. Examination of antifungal activity using the disc diffusion method. Candida suspension are removed to Muller Hinton agar supplemented with 2\% glucose and $0.5 \mu \mathrm{g} / \mathrm{mL}$ methylene blue (GMB). Paper disks / disks containing rosemary and fluconazole with different potential are placed on Muller Hinton agar which has been planted with yeast isolates as much as 1x106 CFU / $\mathrm{ml}$ and to be dried at room temperature for 15 minutes. After 15 minutes, $5 \mathrm{~mm}$ of wells were made, and $100 \mu \mathrm{L}$ of rosemary and fluconazole essential oil were deposited into each well. Yeast susceptibility testing by radial diffusion compares the two active ingredients incubated at $37^{\circ} / \mathrm{C}$ for 24 hours, and halo inhibition is measured in millimeters. The zone sizes were interpreted as per Clinical Laboratory Standards Institute (CLSI) guidelines. The obtained results were analyzed using SPSS (mean, standard deviation). The data for diffusion methods were analyzed by MannWhitney in Statistic. Statistical significance was determined at $p \leq 0.05$. This research has been reviewed and approved by the Ethics Committee at Dr. Soetomo General Academic Hospital (1647/KEPK/XI/2019).

\section{RESULT}

The demographic distribution of isolates from HIV / AIDS patients with OC in this study is presented in Table 1 . The male patients were 31 patients $(77.5 \%)$ and female patients were 9 patients $(22.5 \%)$. The age of patients from isolates in this study varied between the age group 15-24 years to 55-64 years. The most age range is 19 subjects $(47.5 \%)$ in the $25-34$ years group the least number in the 55-64 years group is 3 patients (7.5\%). The most common major complaint was white patches in the oral cavity of 36 patients $(90 \%)$, and 23 patients $(57.5 \%)$ accompanied by swallowing pain. The most common type of OC this study were pseudomembranous type, found in 39 patients (88\%), followed by acute type of cheilitis and atrophic each of $4(9 \%)$ and $1(3 \%)$.

Figure 1 shows the inhibition zone formed by fluconazole is greater when compared with rosemary essential oil. The mean value of inhibition zone formed by fluconazole was $17.9 \pm 8.62 \mathrm{~mm}$ while rosemary essential oil was $1.75 \pm 3.64 \mathrm{~mm}$. Shapiro Wilk test confirmed that the data were not normally distributed $(\mathrm{p}<0.05)$; therefore, nonparametric statistical tests, the Mann Whitney test, was performed. The Mann Whitney test results showed a statistically significant difference $(p<0.001)$ between the inhibition zone formed by fluconazole and the inhibition zone formed by rosemary essential oil. 
Table 1. Demographic data of research

\begin{tabular}{|c|c|c|c|c|}
\hline \multirow{2}{*}{ No } & \multicolumn{2}{|r|}{ Basic Data } & \multirow[t]{2}{*}{$\mathrm{N}$} & \multirow[t]{2}{*}{$\%$} \\
\hline & Categories & Group & & \\
\hline \multirow{2}{*}{1} & \multirow{2}{*}{ Gender } & Male & 31 & 77.5 \\
\hline & & Woman & 9 & 22.5 \\
\hline \multirow{6}{*}{2} & \multirow{6}{*}{ Age } & $15-24$ years & 6 & 15 \\
\hline & & $25-34$ years & 19 & 47.5 \\
\hline & & $35-44$ years & 4 & 10 \\
\hline & & $45-54$ years & 8 & 20 \\
\hline & & $55-64$ years & 3 & 7.5 \\
\hline & & $>65$ years & 0 & 0 \\
\hline \multirow{4}{*}{3} & \multirow{4}{*}{ *Major complain } & $\begin{array}{l}\text { Red patches in the oral cavity, patches and } \\
\text { sores on the lip corners }\end{array}$ & 3 & 7.5 \\
\hline & & Red and red patches on the oral cavity & 0 & 0 \\
\hline & & White patches on the oral cavity & 36 & 90 \\
\hline & & $\begin{array}{l}\text { White patches in the oral cavity, patches } \\
\text { and sores on the lip corners }\end{array}$ & 1 & 2.5 \\
\hline \multirow{4}{*}{4} & \multirow{4}{*}{ *Diagnosis } & Pseudomembranous candidiasis & 39 & 88 \\
\hline & & Plaque hyperplasia candidiasis & 0 & 0 \\
\hline & & Atrophic candidiasis & 1 & 3 \\
\hline & & Cheilitis candidiasis & 4 & 9 \\
\hline \multirow{2}{*}{5} & \multirow{2}{*}{ Pain } & Yes & 23 & 57.5 \\
\hline & & No & 17 & 42.5 \\
\hline \multirow{2}{*}{6} & \multirow{2}{*}{ Total CD4 absolute } & $<200 \mathrm{sel} / \mu \mathrm{L}$ & 28 & 70 \\
\hline & & $>200 \mathrm{sel} / \mu \mathrm{L}$ & 12 & 30 \\
\hline
\end{tabular}

* Patients can have $>1$ major complaint, diagnosis.

\section{Candida Albicans}

$$
\begin{array}{r}
12 \\
10 \\
8 \\
6 \\
4 \\
2 \\
0 \\
-2 \\
-4
\end{array}
$$

DRUGS

Figure 1. The diameter inhibition zone of Candida albicans growth between fluconazole and rosemary 


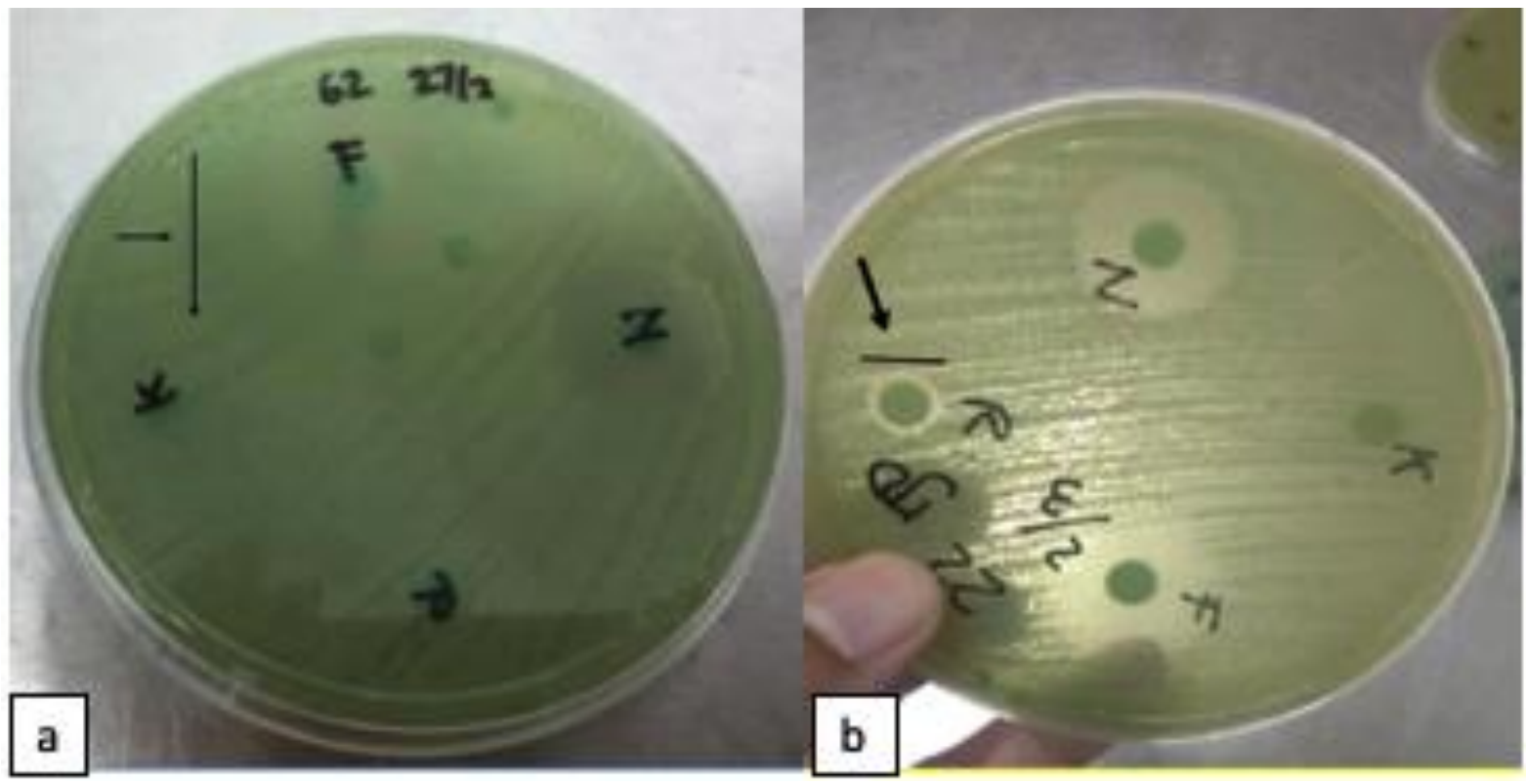

Figure 2. Inhibition zones against $C$. albicans a. fluconazole with diameters $30 \mathrm{~mm}$ b. rosemary with diameters $7 \mathrm{~mm}$

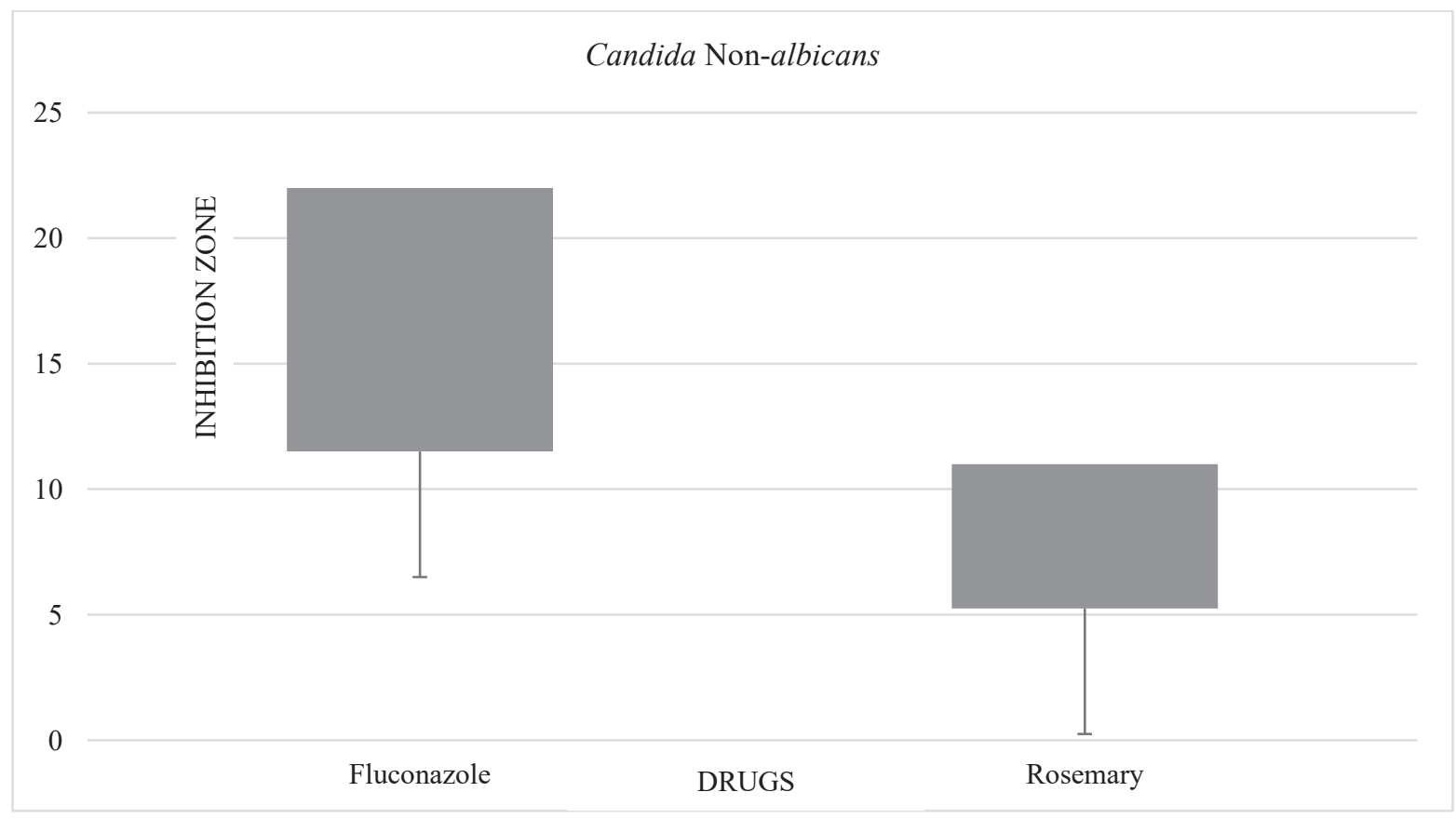

Figure 3. The diameter inhibition zone of Candida non-albicans growth between fluconazole and rosemary essential oil in disc-diffusion assay

Figure 3 shows the inhibition zone formed by fluconazole is greater when compared with rosemary essential oil. The mean value of inhibition zone formed by fluconazole was $4.85 \pm 7.9 \mathrm{~mm}$ while rosemary essential oil was $1.5 \pm 3.08 \mathrm{~mm}$. Shapiro Wilk test confirmed that the data were not normally distributed $(p<0.05)$; therefore, nonparametric statistical tests, the Mann Whitney test, was performed. The Mann Whitney test results showed a no statistically significant difference $(\mathrm{p}>0.05)$ between the inhibition zone formed by fluconazole and the inhibition zone formed by rosemary essential oil.

Based on data from Table 2 and Table 3 shows all of research subject had history of treatment before with fluconazole nystatin and the combination of both. Kruskal Wallis test results showed no significant differences in the inhibition zone formed with a history treatment, on the use of fluconazole or rosemary $(\mathrm{p}>$ $0.05)$ 


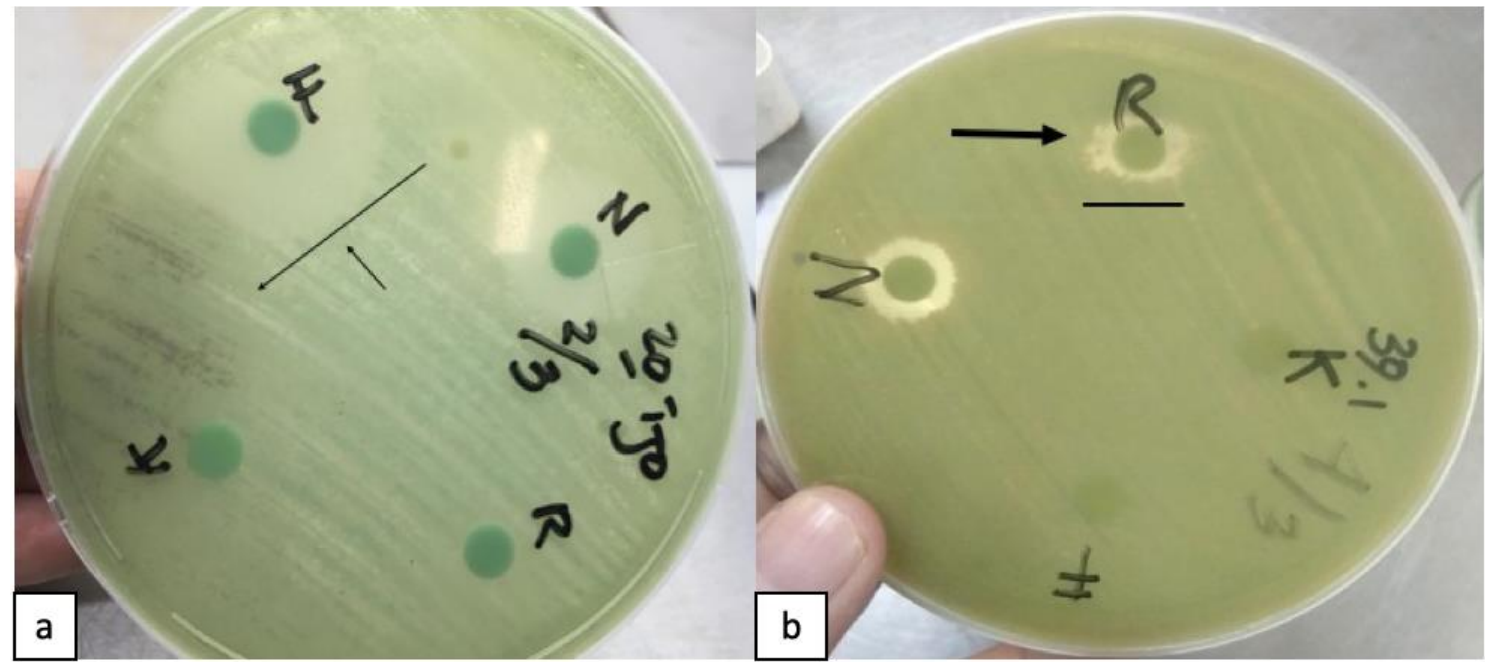

Figure 4. Inhibition zones against $C$. non-albicans a. fluconazole with diameters $22 \mathrm{~mm}$ b. rosemary with diameters $8 \mathrm{~mm}$

Table 2. Correlation between inhibitory zones of $C$. albicans with a history treatment

\begin{tabular}{|c|c|c|c|c|c|}
\hline Drug & History treatment & $\mathrm{N}$ & Mean \pm SD & $\begin{array}{c}\text { Median } \\
(\min -\max )\end{array}$ & Values \\
\hline \multirow[t]{3}{*}{ Fluconazole } & Fluconazole & 5 & $23,4 \pm 3,97$ & $22(20-30)$ & \multirow{3}{*}{0,096} \\
\hline & Nystatin & 9 & $18,3 \pm 7,94$ & $20(0-26)$ & \\
\hline & Fluconazol \& nystatin & 6 & $12,7 \pm 10,27$ & $16(0-24)$ & \\
\hline \multirow[t]{3}{*}{ Rosemary } & Fluconazole & 5 & $0,0 \pm 0,0$ & $0(0-0)$ & \multirow{3}{*}{0,057} \\
\hline & Nystatin & 9 & $3,9 \pm 4,70$ & $0(0-10)$ & \\
\hline & Fluconazole \& nystatin & 6 & $0,0 \pm 0,0$ & $0(0-0)$ & \\
\hline
\end{tabular}

* SD: Standard deviation

Table 3. Correlation between inhibitory zones of Candida non- albicans with a treatment history

\begin{tabular}{|c|c|c|c|c|c|}
\hline Drug & History treatment & $\mathrm{n}$ & Mean \pm SD & $\begin{array}{c}\text { Median } \\
(\min -\max )\end{array}$ & Values \\
\hline \multirow[t]{3}{*}{ Fluconazole } & Fluconazole & 5 & $5,5 \pm 11,00$ & $0,0(0-22)$ & \multirow{3}{*}{0,159} \\
\hline & Nystatin & 9 & $0,0 \pm 0,0$ & $0(0-0)$ & \\
\hline & Fluconazole \& Nystatin & 6 & $7,5 \pm 8,29$ & $5,5(0-21)$ & \\
\hline \multirow[t]{3}{*}{ Rosemary } & Fluconazole & 5 & $2,0 \pm 4,0$ & $0(0-8)$ & \multirow{3}{*}{0,480} \\
\hline & Nystatin & 9 & $2,5 \pm 3,89$ & $0(0-8)$ & \\
\hline & Fluconazole \& Nystatin & 6 & $0,7 \pm 2,21$ & $0(0-7)$ & \\
\hline
\end{tabular}

* SD: Standard deviation

\section{DISCUSSIONS}

The basic characteristics of the research subjects are presented in Table 1, showing that there were more male subjects than female $(77.5 \%$ and $22.5 \%)$. This research supports a report from the Ministry of Health of the Republic of Indonesia in 2017 that the proportion of male patients is twice as frequent as women. This is related to the number of HIV / AIDS patients more in men. ${ }^{3}$ The most age group is in the age range of 25-34 years with 19 subjects $(47.5 \%)$, this finding is similar to the statement in research by Putranti et al in 2018, that HIV infection is more common in adulthood which makes it more likely to engage in unsafe sexual behavior that is at risk of HIV transmission. ${ }^{13}$

Most of these patients complained of the presence of white patches in the oral cavity of 36 patients $(90 \%)$, and 23 patients $(57.5 \%)$ accompanied by swallowing pain. This condition can be caused by Candida sp. attached to the mucosal surface of the oral cavity or the tongue through its hyphae can be detached and leave a red mucosa and sometimes accompanied by mild bleeding. This can cause pain and burning in the oral cavity as a sign of inflammation. ${ }^{2}$ Complaints white patches in the mouth found in knockout type of pseudomembranous and hyperplasia of plaque is the most common type of OC. Fourty of Candida species 
as research subjects, most were taken from HIV / AIDS patients with OC who had an absolute CD4 count $<200$ cells / $\square$ L of 28 patients (70\%). This finding is similar to the statement in research by Nugraha et al in 2018, OC patients were more likely to be found in patients with an abosolut CD4 cell count $<200$ cells / $\square$ L of 61 patients $(89.71 \%)$. This is related to the pathogenesis of HIV / AIDS in OC. Interaction between HIV TransActivating Transduction or Transcriptional Activator (TAT) protein with $C$. albicans cell wall enables the occurrence of specific gene transduction in HIV / AIDS with CD4 T lymphocyte counts $<200$ cells / $\square$ L. $^{14}$

The results obtained in the study of inhibition zone measurements showed the average diameter of inhibition zone of $C$. albicans formed by fluconazole was $17.9 \pm 8.62 \mathrm{~mm}$ and rosemary essential oil formed was $1.75 \pm 3.64 \mathrm{~mm}$. The Mann Whitney test results showed a statistically significant difference $(p<0.001)$ between the inhibition zone formed by fluconazole and the inhibition zone formed by rosemary essential oil. These results are adjusted to the standard criteria from the Clinical and Laboratory Standards Institute (CLSI) for the sensitive, intermediate, or resistant criteria of each antifungal drug and from the measurement results found that fluconazole is included in the criteria of intermediate and rosemary essential oil there is no standards measurement criteria until now. The results showed the inhibitory zone created by fluconazole growth of Candida non-albicans was greater when compared to rosemary essential oil. The mean value of inhibitory zones that form fluconazole is $4.85 \pm 7.9 \mathrm{~mm}$ while rosemary essential oil is $1.5 \pm 3.08 \mathrm{~mm}$. The mean value of inhibitory zones that form fluconazole is included in the resistant category. Candida nonalbicans species included in this study consisted of 9 species of $C$. krusei, 4 species of $C$. glabrata, 2 species of $C$. dubliniensis, 2 species of $C$. parapsilosis, 2 species of C. tropicalis, and 1 species of C. lypoitica. This study shows that the zone of inhibition of fluconazole determines the greatest of 2 species of $C$. dubliniensis, with diameters of $22 \mathrm{~mm}$ and $21 \mathrm{~mm}$ respectively, which are classified as sensitive categories. Fluconazole inhibition zone in Candida non-albicans species included in the intermediate category is 1 species of $C$. parapsillosis, where the diameter value is $15 \mathrm{~mm}$. Fluconazole inhibition zone in resistant Candida non-albicans species are $9 C$. krusei, 4 C. glabrata species, 1 C. parapsilosis species, 2 C. tropicalis species, and 1 C. lypoitica species. ${ }^{15}$

Result of fluconazole resistant in this study were $50 \%$ consist of $(10 \%$ C. albicans and $40 \%$ Candida non-albicans). The results of this study indicate the fluconazole resistance of Candida non-albicans species, the data are in accordance with the results of a study conducted by Murtiastutik et al in 2019 about the sensitivity of antifungal fluconazole to $C$. species in HIV / AIDS patients in Dr. Soetomo at $48 \%$ and the most species are Candida non-albicans. ${ }^{10}$ The mechanism of fluconazole resistance in Candida nonalbicans species varies depending on each species, and is grouped into two namely intrinsic resistance and extrinsic resistance. Intrinsic resistance associated with Candida species causing OC has occurred since the beginning of antifungal therapy without any prior drug exposure (primary resistance). Fluconazole is intrinsically resistant to several Candida non-albicans species, such as C. krusei, C. glabrata. Extrinsic resistance occurs due to the use of antifungal drugs that are widespread, not according to the dosage and standard, and not according to indications in HIV / AIDS patients causing changes and mutations in the genes in Candida. C. krusei in particular has a low affinity of the ERG11 gene naturally (intrinsically) so that the fluconazole drug cannot bind to the ERG11 protein, C. glabrata has the ability to absorb exogenous sterols so that changes in the composition of the fungal cell membrane are not recognized by the azole antifungal, $C$. tropicalis has the ability inactivating the ERG3 gene that causes changes in the composition of the fungal membrane sterols and both species are also able to increase the expression of the ERG11 gene which causes the azole agent to not bind. ${ }^{16}$

The results of research on the presence of antifungal activity of rosemary essential oil on the growth of $C$. albicans and Candida non-albicans by invitro are still different. The statistical test results obtained mean fluconazole inhibition zone is greater than rosemary essential oil, this is possible because of several factors from the tested drug or from the implementation of the research itself. Rosemary essential oil is more volatile than fluconazole, thus allowing the amount of active ingredients to evaporate before diffusing on paper discs that can reduce its effectiveness. Research on antifungal activity with essential oil often produces data that contradicts the theory, because there is no standard technique for evaluating antifungal using essential oil that have been standardized by CLSI. ${ }^{11}$ Previous research conducted by Delich et al. in 2013 showed the inhibition zone diameter in $11.17 \pm 0,19$ and fluconazole was resistent. The difference in the results of the inhibition zone diameter in this study with the research conducted by Delich et al is in the diffusion method carried out. This study uses the disk diffusion method while the research of Delich et al used agar well diffusion method for the antifungal activity of essential oil the results are often inconsistent, because of the factors of volatility, water solubility and viscosity. ${ }^{12}$ 


\section{REFERENCE}

1. Moges B, Bitew A, Shewaamare A. Spectrum and the in vitro antifungal susceptibility pattern of yeast isolates in Ethiopian HIV patients with oropharyngeal candidiasis. Int J Micro 2016; 2016: $1-8$

2. Kundu RV, Garg A. Yeast Infection: Tinea (Pityriasis) Versicolor, Malassezia (Pityrosporum) Folliculitis. In: Goldsmith LA, Katz SI, Gilchrest BA, Paller AS, Leffell D, Wolff K, editors. Fitzpatrick's Dermatology in General Medicine. $8^{\text {th }}$ ed. New York: McGrawHill; 2012. p. 2298-311.

3. Direktorat Jendral Pengendalian Penyakit dan Penyehatan Lingkungan Kementerian Kesehatan. Situasi penyakit HIV \& AIDS di Indonesia. Jakarta: Ditjen PP \& PL Kementerian Kesehatan RI; 2016. Available from: http://www. pusdatin.kemenkes.go.id/ (Accessed: 05 August 2019)

4. Shahapur PR, Bidri RC. Recent trends in the spectrum of opportunistic infections in Human Immunodeficiency Virus infected individuals on antiretroviral therapy in South India. J Nat Sci Biol Med 2014; 5(2): 392-6.

5. Dewi ISL, Hidayati AN. Manifestasi kelainan kulit pada pasien HIV dan AIDS. BIKKK 2015; 27(2): 97-105.

6. Reza NR, Sugiman T, Basuki S. Uji kepekaan in vitro flukonazol terhadap spesies Candida penyebab kandidiasis oral pada pasien HIV/AIDS dengan Vitek II. BIKKK 2017; 29(3): 234-42.

7. Widaty S, Soebono H, Nilasari H, Listiawan MY, Siswati AS, Triwahyudi D, et al, editors. Panduan Praktik Klinis Bagi Dokter Spesialis Kulit dan Kelamin di Indonesia. Jakarta: PP Perdoski; 2017.

8. Suyoso S, Ervianti E, Barakbah J. Kandidiasis Mukosa. In: Suyoso S, Ervianti E, Barakbah J, editors. Panduan praktik klinis SMF Ilmu Kesehatan Kulit dan Kelamin RSUD Dr. Soetomo, Surabaya 2014. p. 95-7.
9. Sobel JD, Akins RA. The role of resistance in candida infections: Epidemiology and treatment. In: Mayer DL, Sobel JD, Ouellette M, Kaye KS, Marchaim D, editors. Antimicrobial drug resistance. $2^{\text {nd }}$ ed. New York: Springer International Publishing 2017. p. 1075-997.

10. Murtiastutik D, Maharani CS, Rahmadewi. Profile of Candida resistancy of fluconazole in male patient with oral candidiasis and HIV/AIDS. J AIDS Clin Res 2019; 10:1-6.

11. Gauch L, Pedrosa SS, Esteves RA, SilvieraGomes F, Gurgel ESC, Arruda AC, et al. Antifungal activity of Rosmanirus officinalis Linn. essential oil against Candida albicans, Candida dubliniensis, Candida parapsilosis and Candida krusei. Rev Pan-Amaz Saude 2014; 5: 61-6.

12. Delich DN, Skrobonja JR, Karaman MA, Matavulj MN, Bogavac MA. Antifungal activity of essential oils of Origanum vulgare and Rosmarinus officinalis against three Candida albicans strains. J Nat Sci 2013; 124: 203-11.

13. Putranti A, Asmarawati TP, Rachman BE, Hadi U, Nasronudin. Oral Candidiasis clinical manifestation of HIV/AIDS infection in Airlangga University hospital patients. ICTROMI 2018; 125:1-6.

14. Nugraha AP, Ernawati DS, Parmadiati AE, Soebadi B, Triyono EA, Prasetyo RA, et al. Prevalence of Candida species in oral candidiasis and correlation with CD4+ count in HIV/AIDS patients in Surabaya, Indonesia. J Int Dent Med 2018; 11:1-5.

15. Barbara DA, Gary WP, Philippe D, Jeff F, Annette WF, Ghannoum MA, et al. M60: Performance standards for antimicrobial disk susceptibility. CLSI 2018;37: 1-3.

16. Whaley SG, Berkow EL, Rybak JM, Nishimoto AT, Barker KS, Rogers PD, et al. Azole Antifungal Resistance in Candida albicans and Emerging Non- albicans Candida Species. Front Microbiol 2017; 7(January): 1-12. 